Acta Universitatis Wratislaviensis • No 4055

Literatura i Kultura Popularna XXVII, Wrocław 2021

https://doi.org/10.19195/0867-7441.27.18

\title{
Adriana Dziemitko
}

ORCID: 0000-0003-0929-0860

Uniwersytet Wrocławski

\section{Jutro należy do kotów. Problemy (eco) science fiction w powieści Bernarda Werbera}

\begin{abstract}
Słowa kluczowe: science fiction, fantastyka ekologiczna, Bernard Werber, kot, posthumanizm, szowinizm gatunkowy
\end{abstract}

Keywords: science fiction, eco-science fiction, Bernard Werber, cat, posthumanism, specism

Dlaczego jutro miałoby nie należeć do ludzi, a do innego gatunku? Science fiction zdaje się odpowiadać na to pytanie, podając zatrważająco trafne argumenty. Nie potrafimy stworzyć bezkonfliktowej wspólnoty międzygatunkowej, nie chcemy zrozumieć innych gatunków i ich nie szanujemy, jesteśmy samolubni i narcystyczni. Niełatwo uświadomić sobie, jak ogromny wpływ na nasze działanie ma perspektywa antropocentryczna. Teksty SF są prognozami, przewidującymi przyszłość, ale również oceną i krytyką teraźniejszości. Najchętniej przyjmujemy te wizje, w których człowiek jest autorem innowacyjnych technologii i postępu kulturowo-ekonomicznego. A co, jeśli to nie rasie ludzkiej jest pisany taki rozwój, a na przykład małpom lub kotom? Niniejszy esej jest próbą analizy powieści Bernarda Werbera Jutro należy do kotów z perspektywy ogólnej problematyki literatury popularnonaukowej oraz ecofiction.

Wśród wyobrażeń świata w odległej przyszłości lub innej galaktyce, ukazujących rozwój technologii znacząco wpływającej na życie człowieka, pojawiła się odmiana science fiction, która podejmuje problem wpływu człowieka na przemiany (zwykle negatywne) środowiska i przyrody. Utwory eco science fiction lub ecofiction, czyli fantastyka ekologiczna ${ }^{1}$, podkreślają znaczenie interesu innego od ludzkiego gatunku oraz procesualny charakter środowiska (podlega ono prze-

${ }^{1}$ Leksykon polskiej literatury fantastycznonaukowej w definicji tego pojęcia skupia się głównie na aspekcie wpływu człowieka na środowisko. Zob. A. Smuszkiewicz, Fantastyka ekologicz- 
mianom, nie jest stałe ani ciągłe) $)^{2}$. Poruszona zostaje jednocześnie kwestia szowinizmu gatunkowego oraz sposobów, w jaki przejawia się on w literaturze.

Termin ecofiction zaczął funkcjonować w Stanach Zjednoczonych w latach sześćdziesiątych i siedemdziesiątych XX wieku, a jego pojawienie się było następstwem wzrastającej w społeczeństwie świadomości ekologicznej ${ }^{3}$. Zjawisko to zaistniało między innymi za sprawą nagłośnionych przez media wydarzeń, takich jak kontrowersyjna budowa tamy Glen Canyon czy publikacja Silent Spring (1962) autorstwa Rachel Carson ${ }^{4}$, uświadamiająca ludziom negatywny wpływ toksycznych pestycydów na środowisko. Rozumienie świata przyrody przez pryzmat ekologii zyskało wówczas popularność nie tylko w środowisku naukowym, ale też wśród dziennikarzy, co doprowadziło do popularyzacji perspektywy ekologicznej ${ }^{5}$. Te wydarzenia poprzedziły i być może w pewnym stopniu zainspirowały powstanie tekstów z gatunku ecofiction nie tylko w USA. Jedną z pierwszych powieści fantastycznonaukowych podejmujących tematykę ekologii jest Diuna (Dune, 1965; wyd. pol. 1985) Franka Herberta ${ }^{6}$. Do innych ważnych i prekursorskich powieści oraz opowiadań science fiction lat sześćdziesiątych i siedemdziesiątych, które stawiają istotne pytania o rolę człowieka w środowisku, należą między innymi: Non-stop (1958; wyd. pol. 1975) i Cieplarnia (Hothouse, 1962; wyd. pol. 1983) Briana Aldiss'a ${ }^{7}$, Szerzej niz imperia $i$ wolniej (Vaster than Empires and More Slow, 1971; wyd. pol. 1980) Ursuli K. Le Guin, a także Ślepe stado (The Sheep Look Up, 1972; wyd. pol. 2016) Johna Brunnera ${ }^{8}$.

Do klasycznego grona bohaterów science fiction, poza ludźmi, należą roboty, cyborgi, androidy lub przybysze z innej planety (kosmici). Ich humanoidalny charakter - antropomorficzne cechy wyglądu, zachowanie, rozwój gatunku w postaci (s)tworzonej cywilizacji i kultury — sprawia, że człowiek przestaje być gatunkiem górującym nad pozostałymi wiedzą czy osiągnięciami. Tym samym, za sprawą takich powieści, antropocentryczna perspektywa, z której oglądany był

na, [w:] A. Niewiadowski, A. Smuszkiewicz, Leksykon polskiej literatury fantastycznonaukowej, Poznań 1990, s. 277-278.

${ }^{2}$ L. Buell, The Environmental Imagination. Thoreau, Nature Writing, and the Formation of American Culture, Cambridge 1995, s. 7-8, cyt. za: L. Desblache, Bernard Werber's Poetics of Ecological Reconstruction: “In Praise of Amnesia”?, „L'Esprit Créateur” 57, 2017, nr 1, s. 71, https:// bit.ly/3wUjadX (dostęp: 26.06.2020).

3 J. Levin, Contemporary Ecofiction, [w:] C. Eby, B. Reiss, The Cambridge History of the American Novel, Cambridge 2011, Cambridge Core, https://bit.ly/2UWELVY (dostęp: 23.05.2021).

4 Zob. L.J. Lear, Rachel Carson's “Silent Spring”, ,Environmental History Review” 17, 1993, nr 2, s. 23-48, https://bit.ly/36Qbr64 (dostęp: 23.05.2021).

5 J. Levin, op. cit.

${ }^{6}$ V. Kratz, Frank Herbert's Ecology and the Science of Soil Conservation, „NiCHE: Network in Canadian History \& Environment”, https://bit.ly/3Bj2gcI (dostęp: 23.05.2021).

7 M. Ashley, Transformations. The Story of the Science Fiction Magazines from 1950 to 1970, Liverpool 2005, s. 148.

8 E. Otto, Science Fiction and the Ecological Conscience (niepublikowana rozprawa doktorska), University of Florida 2006, s. 15, 30, https://bit.ly/3ritprz (dostęp: 23.05.2021). 
do tej pory świat, traci rację bytu. Człowiek zdaje sobie sprawę z istnienia innych rozumnych gatunków, gdy okazuje się, że w całym wszechświecie nie wyróżnia nas język i możliwość porozumiewania się? . Problemem bardziej ambitnej literatury science fiction stała się właśnie komunikacja międzygatunkowa, do której nawiązania nie zawsze jesteśmy zdolni. (Natomiast według innego modelu SF to ten drugi gatunek albo nie jest skory do wejścia w relację, bo próbuje nas zjeść, albo mówi w powszechnym w całym kosmosie języku angielskim. Takie założenie dobitnie świadczy o zapatrzeniu w siebie homo sapiens, i to zapatrzeniu, z którego nie zdajemy sobie sprawy) ${ }^{10}$. Kontrast między przekonaniem o wyjątkowości człowieka we wszechświecie a prawdą, jaka wybrzmiewa z powieści ${ }^{11}$, przedstawiających niejednokrotnie niepokojąco prezentującą się przyszłość rasy ludzkiej, polega na zakwestionowaniu znaczenia/wartości człowieka i głębokim namyśle nad kondycją człowieczeństwa. Znamienne jest, że istoty przypominające pod wieloma względami człowieka bardzo często są przez niego lekceważone lub nawet uważane za gorsze czy niebezpieczne, co stanowi niekwestionowaną podstawę, wręcz moralne prawo do ich unieszkodliwienia, wypędzenia, a najczęściej — unicestwienia. Są to przejawy szowinizmu gatunkowego — przekonania, że ,jesteśmy jedynymi wartościowymi istotami żyjącymi na Ziemi [i poza nią - A.D.]. Tylko rodzaj ludzki — jak sądzi człowiek — może być zatem tak podmiotem, jak i przedmiotem etyki i moralności"12.

Pojęcie szowinizmu gatunkowego zostało użyte po raz pierwszy przez Richarda Rydera w broszurze o eksperymentach na zwierzętach ${ }^{13}$, które to działania są jednym z przejawów tego zjawiska, zaraz obok mięsnej hodowli przemysłowej, hodowli zwierząt na futra, polowania i wielu innych ${ }^{14}$. Zdroworozsądkowa analiza Petera Singera pozwala ustalić podstawy oraz granice szowinizmu gatunkowe-

${ }^{9}$ Oczywiście nie jest to zupełny wymysł wyobraźni literackiej. Zwierzęta również potrafią się komunikować oraz utrzymywać kontakt, aczkolwiek według specjalistów z zakresu nauk biologicznych umiejętność ta nie rozwinęła się u żadnego gatunku tak dalece jak u człowieka. Zob. E.O. Wilson, Socjobiologia, Poznań 2000, s. 105-106, 116.

10 J. Sobota, Granice komunikacji. Dramat epistemologiczny w literaturze fantastycznonaukowej, [w:] Dyskurs: aspekty lingwistyczne, semiotyczne i komunikacyjne, red. A. Kiklewicz, I. Uchwanowa-Szmygowa, Olsztyn 2015, s. 121.

11 Mam tu na myśli w dużej mierze dystopie przybierające rozmaite kształty, na przykład $C z y$ androidy śniq o elektrycznych owcach? (Do Androids Dream of Electric Sheep?, 1968; wyd. pol. 1995) Philipa K. Dicka, Dawcę (The Giver, 1993; wyd. pol. 2003) Lois Lowry, Więźnia labiryntu (The Maze Runner, 2009; wyd. pol. 2011) Jamesa Dashnera, Metro 2033 (Mempo 2033, 2005; wyd. pol. 2010) Dmitrija Głuchowskiego i inne.

12 J. Lejman, Człowiek a zwierzę. Biologiczne i kulturowe źródła antropocentryzmu, „Wschodni Rocznik Humanistyczny" 11, 2015, s. 284-285.

13 P. Singer, Wstęp, [w:] W obronie zwierząt, red. P. Singer, przeł. M. Betley, Warszawa 2011, s. 10 .

14 P. Singer, Wyzwolenie zwierząt, przeł. A. Alichniewicz, A. Szczęsna, Warszawa 2018, s. $78-79$. 
go $^{15}$, koncentrując się na zagadnieniach moralnych: zadawaniu bólu i odbieraniu życia. Singer w długich rozważaniach stara się udowodnić, że życie ludzkie nie zawsze jest cenniejsze od zwierzęcego, i przekonuje, że każdy byt ma taką samą wartość. Jednym z ciekawszych zabiegów myślowych australijskiego etyka jest przedstawienie czytelnikowi abstrakcyjnej sytuacji, w której to przyjaźnie nastawiony obcy dzwoni do naszych drzwi:

Jeśli kosmita zdolny jest mieć świadomą wolę trwania życia — już samo to jest powodem, by go nie zabijać. Lecz są także inne: jeśli może cieszyć się życiem, ma krewnych, których jego śmierć okryje żałobą, lub towarzyszy, którzy będą się obawiać, że ich też ktoś zastrzeli. Te cztery powody, dla których moralnie złe jest zabicie pukającej do drzwi osoby, stosują się tak samo do przybyszów z innych planet [...]. Odrzucenie ,gatunkowizmu” znaczy tylko tyle, że gatunek istoty dzwoniącej do drzwi nie jest cechą moralnie znaczącą ${ }^{16}$.

Singer daje do zrozumienia, że istoty nie-ludzkie pod względami etycznymi niczym nie różnią się od homo sapiens. Przez długi czas wykluczane w kulturze i marginalizowane $\mathrm{w}$ dyskursie publicznym zwierzęta zyskały obecnie szerokie audytorium, również w języku widać tendencje do nieantroponormatywności ${ }^{17}$, świadomego zrezygnowania z gatunkowej dominacji ${ }^{18}$. Odrzucenie szowinizmu gatunkowego w języku poetyckim (a można wszak to stwierdzenie odnosić także do prozy) miałoby polegać, posługując się sformułowaniami Anity Jarzyny, na niewyróżnianiu ludzkiej pozycji i podmiotu spośród innych gatunków ${ }^{19}$. Badaczka takie wywyższenie człowieka w narracji nazywa nawet przemocą, którą należy zwalczać, włączając zwierzęta do przestrzeni komunikacji na równi z ludźmi ${ }^{20}$.

Wizje ,uczłowieczonej” sztucznej inteligencji lub rozumnych obcych to nie jedyny sposób na wyrażenie krytycznego stanowiska autora wobec poglądu, według którego człowiek miałby być stworzeniem doskonałym ${ }^{21}$. Kontrastujące $\mathrm{z}$ sobą obrazy człowieka i Innego, w którego roli są zwykle obsadzane wcześniej wymienione byty, w literaturze science fiction obnażają braki i ułomności ludzkości, a także zmianę definicji człowieczeństwa lub jej rozszerzenie ${ }^{22}$. Funkcję Innego

${ }^{15}$ Są to między innymi jasno określone różnice między gatunkami i ich potrzebami oraz założenie, że zwierzęta czują. Zob. P. Singer, Wstęp..., s. 12-15; idem, Wyzwolenie zwierząt..., s. 53-79.

16 P. Singer, O życiu i śmierci. Upadek etyki tradycyjnej, przeł. A. Alichniewicz, A. Szczęsna, Warszawa 1997, s. 222.

17 A. Jarzyna, Post-koiné. Studia o nieantropocentrycznych językach (poetyckich), Łódź 2019, s. 41.

18 Ibidem, s. 531.

19 Ibidem, s. 42.

20 Ibidem, s. 43.

21 V. Graaf, Homo futurus. Analiza współczesnej science fiction, przeł. Z. Fonferko, Warszawa 1971, s. 45.

22 A. Urbańczyk, Okrutne, zimne rzeczy. Etyczne kryteria człowieczeństwa w twórczości Philipa K. Dicka na przykładzie „Czy androidy marza o elektrycznych owcach?”, [w:] Oblicza Przedmiotów, red. M. Błaszkowska, K. Bolęba-Bocheńska, Kraków 2019, s. 25-26, https://bit.ly/ mprzedm-urbanczyk (dostęp: 26.06.2020). Zob. także M. Marcela, Bardziej ludzcy niż ludzie: cy- 
może jednak przejąć stworzenie znacznie bliższe i dłużej znane człowiekowi niż przybysz z obcej planety lub twór wysoko rozwiniętej technologii — zwierzę.

Zwierzęta, które wiele wieków temu człowiek uprzedmiotowił i odarł z tożsamości, świadomości, empatii i innych cech przypisywanych wyłącznie ludziom, obecnie za sprawą nauki nabierają bardziej podmiotowego charakteru: „Z najnowszych badań wynika, że zwierzęta obdarzone są dużo bardziej rozwiniętymi zdolnościami poznawczymi i społecznymi, niż sądziliśmy" "23. Podziały wykreowane przez człowieka (w uproszczeniu: na domowych pupili i potencjalne mięso) umożliwiły wykluczenie niektórych gatunków z ram bios i $d z o \bar{e}$, sprowadzenie ich do kategorii nagiego życia ${ }^{24}$, a co za tym idzie — ich nieludzkie (!) traktowanie $^{25}$. Jednakże posthumanistyczna perspektywa ${ }^{26}$, zyskująca coraz więcej zwolenników w dyskursie publicznym, zwraca uwagę na te nierówności. Tendencja do krytycznej oceny postawy szowinistycznej (zarówno względem tworów rodem z powieści fantastycznonaukowych, jak i zwierząt) przejawia się również w literaturze, a science fiction nie jest wyjątkiem. Kanonicznym przykładem są tu manifesty Donny Haraway ${ }^{27}$. Z kolei Sherryl Vint w pracy Animal Alterity (2011) łączy science fiction oraz animal studies wspólnymi celami badawczymi:

Obie dziedziny stawiają podstawowe pytania o naturę ludzkiej egzystencji i socjalizacji. Obie skupiają się na odmienności i znaczeniu, jakie posiada ta odmienność dla innego. Wreszcie obie traktują niezmiernie poważnie pytanie o możliwość porozumienia z istotami diametralnie różnymi od nas ${ }^{28}$.

Już w 1963 roku Pierre Boulle w Planecie matp (La Planète des singes, 1963; wyd. pol. 1980) zestawił z sobą człowieka i małpę, a rzeczywistość, w jakiej te dwa gatunki się znalazły, przyniosła odwrócenie ich ról względem stanu współczesnego ${ }^{29}$. Wizja przyszłości, w której człowiek traci swój status gatunku do-

borgi - androidy - replikanci, „Creatio Fantastica” 2015, nr 1, https://bit.ly/3Bg9BJT (dostęp: 26.06.2020).

23 P. Skubała, Czy odkrycia nauk biologicznych moga zmienić nasz stosunek do zwierząt?, [w:] Człowiek w relacji do zwierząt, roślin i maszyn w kulturze, t. 1, red. J. Tymieniecka-Suchanek, Katowice 2014, s. 21.

${ }^{24}$ G. Agamben, Homo sacer. Suwerenna władza i nagie życie, przeł. M. Sława, Warszawa 2008, s. 125.

25 Marcin Czerwiński przywołuje przykład zwierząt rzeźnych, które można „ze szczególnym okrucieństwem poddać ubojowi rytualnemu" - idem, Pomiędzy etyka a estetyka transgatunkową. Od Agambena — przez sztuke — do Welscha, [w:] Człowiek w relacji do zwierząt..., t. 1, s. 147.

26 Zob. G. Gajewska, Posthumanistyka, [w:] eadem, Arcy-nie-ludzkie. Przez science fiction do antropologii cyborgów, Poznań 2010, s. 44-60.

27 D. Haraway, Manifest cyborgów, przeł. S. Królak, E. Majewska, „Przegląd Filozoficzno-Literacki” 2003, nr 1, s. 49-87; eadem, Manifest gatunków stowarzyszonych, przeł. J. Bednarek, [w:] Teorie wywrotowe. Antologia przekładów, red. A. Gajewska, Poznań 2012, s. 241-260.

28 Cyt. za: A. Nieracka, Kilka uwag o obecności zwierząt w filmie i literaturze science fiction, „ZOOPHILOLOGICA. Polish Journal of Animal Studies” 2016, nr 2, s. 107, https://bit.ly/3BieT7J (dostęp: 26.06.2020).

29 P. Boulle, Planeta matp, przeł. K. i K. Pruscy, Warszawa 2014. 
minującego, a przejmuje go zwierzę, zdolne do tworzenia i rozwijania kultury i technologii ${ }^{30}$, jest próbą zwrócenia uwagi na wcześniej wymienione kwestie: szowinizmu gatunkowego i funkcjonowania Innego w powszechnej świadomości.

W wypadku Planety matp czytelnik (lub widz oglądający ekranizacje powieści) zdaje sobie sprawę, że znalazł się w świecie wartości odwróconych, w którym człowiek jest uważany za istotę podrzędną, intruza i musi dowieść swojej wartości, by móc przetrwać we wrogim otoczeniu, mimo wszystko pozostając na łasce małp. Ukazanie podmiotowości Innego - zwierzęcia, która może być równie bogata co ludzka, jest często elementem literatury fantastycznonaukowej podnoszącym jej atrakcyjność w oczach odbiorcy. Chyba każdy zastanawiał się kiedyś, co myślą i czują zwierzęta, a dowodem na to są badania, które powoli odkrywają przed nami sekrety struktur myślowych i komunikacyjnych poszczególnych gatunków ${ }^{31}$. Agnieszka Nieracka podaje przykłady tekstów kultury z gatunku science fiction, w których zwierzęta (za sprawą wpływów feministycznych i cyberpunkowych, a więc dyskursów koncentrujących część swojej uwagi na zagadnieniu Innego) są punktem odniesienia rozważań z gruntu postantropocentrycznych. Są to między innymi opowiadania Ursuli Le Guin z tomu Dziewczyny Buffalo i inne zwierzece obecności (Buffalo Gals, Won't You Come Out Tonight, 1987; wyd. pol. 1994), Zakochana Rachela (Rachel in Love, 1987; wyd. pol. 1988) Pat Murphy, Święty płomień (Holy Fire, 1996; wyd. pol. 1997) Bruce'a Sterlinga czy opowiadanie Williama Gibsona Johnny Mnemonic (1981; wyd. pol. 1996) ${ }^{32}$.

Powszechne zarzuty wobec science fiction formułowane przez przeciętnego odbiorcę, którego bynajmniej nie zachwycają fantastyczne wizje pisarzy, zwykle zawierają się w ich rzekomej zmyśloności oraz byciu nieużytecznym elementem kultury popularnej ${ }^{33}$. Środowisko naukowe udowodniło jednak wartość fantastycznonaukowej prozy, która podejmuje zagadnienia epistemologiczne, a także etyczne, tożsamościowe i wiele innych ważkich kwestii ${ }^{34}$.

Za jednego ze współczesnych przedstawicieli tej odmiany eco science fiction uważa się francuskiego pisarza Bernarda Werbera ${ }^{35}$, znanego przede wszystkim z trylogii o mrówkach. Powieść Jutro należy do kotów (Demain les chats,

30 W. Zieliński, Pieśń o Minerwie, czyli kilka słów o relacji kultury i nauki, „Pisma Humanistyczne” 2015, nr 13, s. 67-68, https://bit.ly/2UUIHXs (dostęp: 26.06.2020).

31 P. Skubała, op. cit.

32 A. Nieracka, op. cit.

33 M. Lisek, Science fiction — złudzenie czy proroctwo przyszłości?, „Środkowoeuropejskie Studia Polityczne" 2008, nr 1, s. 237, Repozytorium Uniwersytetu im. Adama Mickiewicza, https:// bit.ly/3zgtcaS (dostęp: 26.06.2020).

34 Zob. m.in. R. Handke, Polska proza fantastycznonaukowa. Problemy poetyki, Wrocław 1969; S. Lem, Fantastyka i futurologia, t. 1-2, Kraków 1970; A. Zgorzelski, Fantastyka, utopia, science fiction. Ze studiów nad rozwojem gatunków, Warszawa 1980; Spór o SF. Antologia szkiców i esejów o science fiction, wyb. R. Handke, L. Jęczmyk, B. Okólska, Poznań 1989.

35 L. Desblache, op. cit. 
2016; wyd. pol. 2018) ${ }^{36}$ opowiada o losach kotki Bastet i jej „służącej” Nathalie. Akcja toczy się w Paryżu, w czasie zamieszek i niepokojów na tle religijnym, które wkrótce przeradzają się w wojnę. Bastet dąży do porozumienia międzygatunkowego, próbuje komunikować się nie tylko ze swoją panią, lecz także ze złotą rybką, psem i innymi stworzeniami, jednak jej starania przynoszą marne efekty. Inne gatunki zamykają się bowiem na starania kotki i możliwość dialogu z przedstawicielem innej rasy. Bastet poznaje sąsiada Pitagorasa, kota syjamskiego z Trzecim Okiem - wejściem USB w głowie, efektem eksperymentu naukowego jego właścicielki Sophie. Dzięki „mocom”, którymi Pitagoras dysponuje za pośrednictwem Trzeciego Oka (nieograniczona wiedza i dostęp do Internetu), oraz niezłomności i determinacji Bastet kocim bohaterom udaje się uratować świat przed inwazją krwiożerczych szczurów, które do przejęcia władzy nad światem jako broń biologiczną wykorzystują przenoszoną przez siebie dżumę ${ }^{37}$. Powieść skupia się na potrzebie porozumienia międzygatunkowego kota (a nie człowieka, który nie rozumie komunikatów nadawanych przez zwierzę), a przede wszystkim - przejęciu inicjatywy „społecznej” przez inną rasę, a więc procesie przejmowania przez koty supremacji w biocenozie.

Werber przedstawia świat oczami kota, wskazuje na pewne zachowania człowieka i zwierząt, które są wyraźnym przekroczeniem paradygmatu antropocenu. To Bastet analizuje zachowania swojej ,służącej”, czasem niezrozumiałe ze względu na różnice gatunkowe, które kwituje w humorystyczny (dla odbiorcy) sposób:

Nathalie [...] depiluje wąsik za pomocą pincety — jest to zachowanie, którego nigdy nie pojmę, nie dość, że ma problemy z utrzymaniem równowagi, to jeszcze, jeśli usunie sobie włoski z pyszczka, będzie upadać częściej i nie będzie w stanie odbierać zewnętrznych fal ${ }^{38}$.

Szowinizm gatunkowy w kocim wydaniu może zaskakiwać i bawić, ponieważ, jak zauważył Hans Jonas, dotychczas etyka była w całości antropocentryczna $^{39}$, nie wyobrażaliśmy sobie więc zwierzęcia, które mogłoby odnosić konkretne kategorie moralne jedynie do swojego gatunku i tym samym pomijać w nich człowieka. Co więcej, Jonas twierdzi, że „egoizm gatunku — każdego gatunku [...] ma pierwszeństwo, zgodnie z porządkiem życia w ogóle, szczególne zaś wykorzystanie swej władzy przez człowieka wobec reszty świata ożywionego stanowi naturalne prawo wynikające z samego jej posiadania"40. Człowiek jako istota obdarzona nieprzeciętnym rozumem i władzą staje się zatem oprawcą natury,

${ }^{36}$ Książka rozpoczyna kolejny literacki cykl Werbera. Drugą jego częścią jest powieść do tej pory nieprzetłumaczona na polski: Sa majesté des chats (2019). Trzecia część trylogii jeszcze się nie ukazała. Zob. idem, Sa majesté des chats, BernardWerber.com, https://bit.ly/3eAQXT (dostęp: 26.06.2020).

37 B. Werber, Jutro należy do kotów, przeł. M. Turnau, Katowice 2018.

38 Ibidem, s. 20.

39 H. Jonas, Zasada odpowiedzialności. Nowa etyka dla cywilizacji technologicznej, przeł. M. Klimowicz, Kraków 1996, s. 27.

40 Ibidem, s. 251. 
mogąc nią dowolnie dysponować, lecz także jej jedyną nadzieją, która tkwi głównie w jego moralności. Odpowiedzialność gatunku ludzkiego miałaby polegać na utrzymaniu przy życiu reszty świata ożywionego, również po to, by zagwananrować własnym przyszłym pokoleniom warunki do przetrwania ${ }^{41}$.

Takie rozumowanie zostaje przełożone na karty omawianej powieści. Bastet obserwuje również takie zdarzenia, które bez względu na perspektywę zdają się po prostu nielogiczne i pozbawione sensu, jak wybuch wojny, której podłożem są starcia na tle religijno-społecznym, oraz zmiany w stanie środowiska, do którego ta wojna prowadzi (zanieczyszczenie ulic, ale też chylenie się cywilizacji ku upadkowi). Jej spojrzenie zdaje się zdroworozsądkowe (poza fragmentami szczególnie humorystycznymi, jak ten już cytowany), kotka dąży także do poszerzenia swojej wiedzy o świecie i przede wszystkim stara się zrozumieć ludzi i inne zwierzęta, prowadzi dogłębne obserwacje, analizy i deliberacje. Stara się na swój sposób pomóc - podziękować, pocieszyć w trudnych chwilach, ostrzec, nakarmić - choć ta pomoc ze względu na barierę gatunkową nie zawsze może zostać odpowiednio zrozumiana, aczkolwiek według rozumowania jonasowskiego Bastet i jej koci przyjaciele przejęli funkcję stworzeń „wyjątkowych” i ich działania były podyktowane egoistycznymi pobudkami.

Typowy „człowiek cywilizowany” w Jutro należy do kotów, reprezentowany przez Thomasa - partnera Nathalie, został natomiast przedstawiony jako pan i władca, osobnik, który „ogłuchł”, zamknął się na głos istot, z którymi przyszło mu dzielić przestrzeń do życia - w tym na głos kobiet i zwierząt, będących dla niego Innymi, przeszkadzającymi w budowaniu świata według własnej wizji ${ }^{42}$. Okrucieństwo Thomasa względem Innego objawia się w dwóch kluczowych momentach: w pierwszym topi on nowo narodzone kocięta Bastet w toalecie. W drugim, kiedy nastaje czas wojennego zamętu i bezprawia, włamuje się wraz z kolegami do domu swojej partnerki Nathalie w celu jej obrabowania, co kończy się złapaniem drugiego kota kobiety — Félixa — i nabiciem go na rożen. Rabusie zabijają również Sophie, właścicielkę Pitagorasa. Te bestialskie akty są manifestacją ludzkiego braku szacunku dla gatunku innego niż własny, i to nie tylko w obliczu stanu wyjątkowego ${ }^{43}$. Nie jest to kwestia instynktu przetrwania (tak zwanego biologicznego szowinizmu gatunkowego, który oznacza „rozpoznawanie relacji »człowiek-inne byty pozaludzkie« w kategoriach dobra gatunku (ludzkiego)"44), a postawy, którą przybrał Thomas. Chodzi tu o hominizm, czyli stanowisko rozważające relację „,człowiek-zwierzę w kategoriach i wedle kryterium rozumu ludzkiego”, zgodnie z którym „zwierzęta jawią się bądź jako bezrozumne automaty (Kartezjusz), bądź mało rozumne byty pozaludzkie"45. Skoro zwierzę po-

\footnotetext{
${ }^{41}$ Ibidem, s. 253-254.

42 A. Nieracka, op. cit., s. 108.

43 G. Agamben, op. cit.

44 J. Lejman, op. cit., s. 285.

45 Ibidem, s. 287.
}

Literatura i Kultura Popularna XXVII, Wrocław 2021

(C) for this edition by CNS 
zbawione jest rozumu, a więc cząstki człowieczej, która stanowi o wartości życia, zabicie go nie stwarza problemu moralnego ${ }^{46}$.

Choć człowiek dysponuje wysoko rozwiniętą technologią (na przykład kot-cyborg i cała aparatura w laboratorium Sophie), nie potrafi jej odpowiednio wykorzystać, doprowadzając do paraliżującej sytuacji społecznej, a w konsekwencji do regresu obyczajowości człowieka. Być może jest to kwestia zaniedbania przez człowieka kultury, ponieważ to właśnie jej rozwój gwarantuje postęp we wszystkich innych dziedzinach ${ }^{47}$. Podczas gdy Bastet i Pitagoras prowadzą dyskusje pogłębiające wiedzę o historii własnego gatunku i zachwycają się utworem Casta Diva z opery Norma Vincenza Belliniego w wykonaniu Marii Callas, Nathalie wciąż przesiaduje przed „wielką czarną deską" - telewizorem, na którym przewijają się głównie obrazy okrucieństwa i przemocy. Nie jest to jednak regres kulturowy na taką skalę, jak przewidywał Boulle w Planecie matp (dzięki interwencji kotów, które ratują ludzi przed szczurami). Walka o niezrozumiałe wartości (różnice religijne) z perspektywy zdroworozsądkowego obserwatora, zdziczenie człowieka, utrata nie tylko ludzkiej godności, ale też takich odruchów, jak litość czy empatia, przypisywanych człowiekowi oraz tchórzostwo (ucieczka prezydenta, który pozostawił w Pałacu Elizejskim swojego kota na pastwę losu) i bezczynność (naukowców, wojska, rządu — nikt nie próbuje powstrzymać katastrofy) to jednak wystarczające przesłanki do zwątpienia w kondycję tej rasy.

Człowiek nie może budować porozumienia i wspólnoty międzygatunkowej, ponieważ wciąż „nie zdołał uporać się ze swoimi wewnętrznymi demonami, skoro wśród jego determinant spoczywa destrukcja i chaos, a świat ludzki wciąż pełen jest wojen i głodu"48. W wizji Werbera ludzkość rozczarowuje, jej postępowanie niesie z sobą zagładę całego humanocentrycznego świata, zbudowanego na wartościach i technologiach stworzonych przez człowieka dla człowieka. Jego upadek i utratę przez niego hegemonii dostrzegamy najwyraźniej, gdy to inny gatunek zdobywa wiedzę i umiejętności, by je obsługiwać, co więcej - inny gatunek chroni człowieka i świat przed zagładą.

Człowiekowi nie udaje się stworzyć pokojowej wspólnoty ze zwierzętami (to znaczy nieopartej na przemocy w szerokim tego słowa znaczeniu), lecz koty także tego nie potrafią - niestety Bastet nie może porozumieć się z zadżumionymi gryzoniami i wraz z kocią armią musi posłużyć się argumentem siły i sprytem. Co więcej - koty, ale i inne zwierzęta, przejawiają szowinizm gatunkowy. U Werbera każdy gatunek jest przekonany o swojej wyższości nad pozostałymi. Bastet uważa, że koty czują, widzą i wiedzą więcej od ludzi, mają też dużo bardziej wrażliwą naturę, a jedyne, czego im brakuje do doskonałości i statusu rasy dominującej, to kciuki. Psy nawet w obliczu światowego zagrożenia martwią się tylko o siebie, szczury sądzą, że są silniejsze od wszystkich stworzeń, przejmu-

\footnotetext{
46 Więcej na ten temat można znaleźć we wcześniej cytowanych pracach Petera Singera.

47 W. Zieliński, op. cit., s. 70.

48 M. Czerwiński, op. cit., s. 138.
} 
ją ich terytoria i zapasy pożywienia, a lew Hannibal jest stereotypowym królem dżungli i okazuje pogardę każdemu ze swych poddanych.

Nie bez znaczenia pozostaje to, że ostatecznie projekt międzygatunkowej komunikacji, do którego realizacji usilnie dążyła Bastet, zostaje w pewnym sensie zakończony sukcesem. Nie jest to bowiem transgatunkowy ideał, o którym pisał Marcin Czerwiński - wspólnota (komunikacyjna) stworzona bez pośrednictwa transcendencji4 ${ }^{49}$. Bastet udaje się porozumieć podczas snu z Patricią, głuchoniemą kobietą uznawaną za szamankę, czarownicę ${ }^{50}$ lub obłąkaną, która deklaruje, że regularnie rozmawia z duszami roślin i zwierząt. Okoliczności pozornie stanowiące barierę komunikacyjną $\mathrm{w}$ tym przypadku jednak sprzyjają osiągnięciu międzygatunkowego porozumienia - misja zostaje wypełniona.

Dialog kociej szamanki z ludzką rozwiewa wszelkie wątpliwości co do przekazu powieści Werbera - to agitacja na rzecz równości wszystkich gatunków. Na zarzuty Bastet w kierunku ludzkich służących, którzy źle wypełniają swoją rolę, bo zamykają koty w mieszkaniach, kastrują je i podają do jedzenia karmę z trocin, Patricia odpowiada, uświadamiając kotkę, że ludzie nie są służącymi zwierząt, a wręcz uważają się za ich panów i panie. Szybko jednak dodaje:

Sądzę, że żaden gatunek zwierząt nie powinien wydawać rozkazów innemu gatunkowi. Ziemia należy w takim samym stopniu do wszystkich form życia zwierzęcego i roślinnego. Żaden gatunek nie ma prawa ogłaszać się ,ponad innymi”. Ani ludzie, ani koty ${ }^{51}$.

Dalej następuje krótka wymiana zdań na temat inności, która według Patricii jest elementem oczarowującej bioróżnorodności ${ }^{52}$. W jej narracji człowiek zostaje włączony do królestwa zwierząt (co jest faktem naukowym przez niektórych zapomnianym). Pod względem ideowym ludzka szamanka przyjmuje animalocentryzm — sposób na walkę z antropocentryzmem i szowinizmem gatunkowym, którego najważniejszym założeniem jest, według Jana Wolańskiego, właśnie uznanie się w pierwszej kolejności za zwierzę, a dopiero w drugiej — za człowieka ${ }^{53}$. W świecie Werbera jest więc miejsce na człowieka, który rozumie etyczną istotę zerwania $\mathrm{z}$ antropocentryzmem. Jednak czy brutalny samiec, taki jak Thomas,

49 Ibidem.

50 Bernard Werber gra tu z konwencją kota-mediatora, mającego dostęp do sfery sacrum i profanum, z czego wynika dwuznaczny status zwierzęcia w kręgu kultury europejskiej: z jednej strony czczonego jako wcielenie bóstw, z drugiej — tępionego jako posłaniec piekieł. Zwierzę często uznawane było za wcielenie czarownicy lub demona, który takiej czarownicy towarzyszył i służył. Zob. P. Kowalski, Kot, [hasło w:] idem, Kultura magiczna. Omen, przesad, znaczenie, Warszawa 2007, s. 241-245; P. Rutkowski, Kot czarownicy. Demon osobisty w Anglii wczesnonowożytnej, Kraków 2012.

51 B. Werber, Jutro należy do kotów..., s. 233.

52 Ibidem, s. 234.

53 J. Woleński, Szowinizm gatunkowy, humanitaryzm i animalocentryzm, „Przegląd Filozoficzny — Nowa Seria” 2015, nr 2 (94), s. 33, https://bit.ly/3ip1fan (dostęp: 26.06.2020). 
zechce podążyć za znakami (a najpierw je jeszcze zauważyć i zrozumieć), jakie daje głuchoniema „wariatka New Age" 54 ?

Mimo wielu wątpliwości względem możliwości ograniczenia szowinizmu gatunkowego i przyjęcia posthumanistycznej postawy przez homo sapiens, w powieści Jutro należy do kotów autor daje nam nadzieję na odwrót od optyki antropocentrycznej. W swojej fantastycznonaukowej wizji Bernard Werber proponuje sposób postępowania i odnajdywania się w nowej rzeczywistości, w której człowiek nie jest już centrum wszystkiego, w której „mechanizmy dzielące i wykluczające” 55 przechodzą do lamusa na rzecz transgatunkowego współbycia i „odczuwania z" ${ }^{56}$.

$\mathrm{Na}$ koniec warto zacytować jeszcze Anitę Jarzynę, której teza badawcza w tym kontekście może stanowić podsumowanie całości niniejszego tekstu, a także, jak się zdaje, intencji pisarskich Werbera:

Poezja bowiem (szerzej: pewna wrażliwość, pewien typ poetyckich działań na języku, nie zawsze przecież objawiających się w wierszu) zaświadcza, że niekoniecznie konwencja realistyczna jest jedynym sposobem nieantropocentrycznego przedstawiania zwierząt. Poezja potrafi zaczarować je ponownie, [...] by ukazywać w ten sposób ich osobność, na nowo zdefiniować ich miejsce w od teraz międzygatunkowym świecie oraz co jeszcze trudniejsze do pogodzenia w zastanym imaginarium — w międzygatunkowej duchowości ${ }^{57}$.

\section{Bibliografia}

\section{Teksty}

Boulle P., Planeta matp, przeł. K. i K. Pruscy, Wydawnictwo Amber, Warszawa 2014.

Werber B., Jutro należy do kotów, przeł. M. Turnau, Wydawnictwo Sonia Draga, Katowice 2018.

\section{Opracowania}

Agamben G., Homo sacer. Suwerenna władza i nagie życie, przeł. M. Sława, Prószyński i S-ka, Warszawa 2008.

Ashley M., Transformations. The Story of the Science Fiction Magazines from 1950 to 1970, Liverpool University Press, Liverpool 2005.

Czerwiński M., Pomiędzy etyka a estetyka transgatunkową. Od Agambena - przez sztukę do Welscha, [w:] Człowiek $w$ relacji do zwierząt, roślin i maszyn $w$ kulturze, t. 1, red. J. Tymieniecka-Suchanek, Wydawnictwo Uniwersytetu Śląskiego, Katowice 2014.

Gajewska G., Arcy-nie-ludzkie. Przez science fiction do antropologii cyborgów, Wydawnictwo Naukowe UAM, Poznań 2010.

Graaf V., Homo futurus. Analiza wspótczesnej science fiction, przeł. Z. Fonferko, Państwowy Instytut Wydawniczy, Warszawa 1975.

54 B. Werber, Jutro należy do kotów..., s. 236.

55 M. Czerwiński, op. cit., s. 138-139.

56 Ibidem.

57 A. Jarzyna, op. cit., s. 41.

Literatura i Kultura Popularna XXVII, Wrocław 2021

(C) for this edition by CNS 
Handke R., Polska proza fantastycznonaukowa. Problemy poetyki, Zakład Narodowy im. Ossolińskich-Wydawnictwo Polskiej Akademii Nauk, Wrocław 1969.

Haraway D., Manifest cyborgów, przeł. S. Królak, E. Majewska, „Przegląd Filozoficzno-Literacki” 2003, nr 1.

Haraway D., Manifest gatunków stowarzyszonych, przeł. J. Bednarek, [w:] Teorie wywrotowe. Antologia przekładów, red. A. Gajewska, Wydawnictwo Poznańskie, Poznań 2012.

Jarzyna A., Post-koiné. Studia o nieantropocentrycznych językach (poetyckich), Wydawnictwo Uniwersytetu Łódzkiego, Łódź 2019.

Jonas H., Zasada odpowiedzialności. Nowa etyka dla cywilizacji technologicznej, przeł. M. Klimowicz, Wydawnictwo Platan, Kraków 1996.

Kowalski P., Kultura magiczna. Omen, przesad, znaczenie, PWN, Warszawa 2007.

Lejman J., Człowiek a zwierzę. Biologiczne i kulturowe źródła antropocentryzmu, „Wschodni Rocznik Humanistyczny" 11, 2015.

Lem S., Fantastyka i futurologia, t. 1-2, Wydawnictwo Literackie, Kraków 1970.

Niewiadowski A., Smuszkiewicz A., Leksykon polskiej literatury fantastycznonaukowej, Wydawnictwo Poznańskie, Poznań 1990.

Rutkowski P., Kot czarownicy. Demon osobisty w Anglii wczesnonowożytnej, Universitas, Kraków 2012.

Singer P., O życiu i śmierci. Upadek etyki tradycyjnej, przeł. A. Alichniewicz, A. Szczęsna, PIW, Warszawa 1997.

Singer P., Wstęp, [w:] W obronie zwierząt, red. P. Singer, przeł. M. Betley, Wydawnictwo Czarna Owca, Warszawa 2011.

Singer P., Wyzwolenie zwierząt, przeł. A. Alichniewicz, A. Szczęsna, Marginesy, Warszawa 2018.

Skubała P., Czy odkrycia nauk biologicznych moga zmienić nasz stosunek do zwierzat?, [w:] Człowiek $w$ relacji do zwierząt, roślin i maszyn $w$ kulturze, t. 1, red. J. Tymieniecka-Suchanek, Wydawnictwo Uniwersytetu Śląskiego, Katowice 2014.

Sobota J., Granice komunikacji. Dramat epistemologiczny w literaturze fantastycznonaukowej, [w:] Dyskurs: aspekty lingwistyczne, semiotyczne i komunikacyjne, red. A. Kiklewicz, I. Uchwanowa-Szmygowa, Centrum Badań Europy Wschodniej Uniwersytetu Warmińsko-Mazurskiego, Olsztyn 2015.

Spór o SF. Antologia szkiców i esejów o science fiction, wyb. R. Handke, L. Jęczmyk, B. Okólska, Wydawnictwo Poznańskie, Poznań 1989.

Wilson E.O., Socjobiologia, Zysk i S-ka, Poznań 2000.

Zgorzelski A., Fantastyka, utopia, science fiction. Ze studiów nad rozwojem gatunków, Państwowe Wydawnictwo Naukowe, Warszawa 1980.

\section{Źródla internetowe}

Desblache L., Bernard Werber's Poetics of Ecological Reconstruction: “In Praise of Amnesia”?, „L'Esprit Créateur” 57, 2017, nr 1, https://bit.ly/3wUjadX (dostęp: 26.06.2020).

Kratz V., Frank Herbert's Ecology and the Science of Soil Conservation, „NiCHE: Network in Canadian History \& Environment", https://bit.ly/3Bj2gcI (dostęp: 23.05.2021).

Lear L.J., Rachel Carson's “Silent Spring”, „Environmental History Review” 17, 1993, nr 2, https:// bit.ly/36Qbr64 (dostęp: 23.05.2021).

Levin J., Contemporary Ecofiction, [w:] The Cambridge History of the American Novel, red. C. Eby, B. Reiss, Cambridge University Press, Cambridge 2011, Cambridge Core, https://bit.ly/2UWELVY (dostęp: 23.05.2021). 
Lisek M., Science fiction - złudzenie czy proroctwo przyszłości?, „Środkowoeuropejskie Studia Polityczne" 2008, nr 1, Repozytorium Uniwersytetu im. Adama Mickiewicza, https://bit. ly/3zgtcaS (dostęp: 26.06.2020).

Marcela M., Bardziej ludzcy niz ludzie: cyborgi — androidy - replikanci, „Creatio Fantastica” 2015, nr 1, https://bit.ly/3Bg9BJT (dostęp: 26.06.2020).

Nieracka A., Kilka uwag o obecności zwierzat w filmie i literaturze science fiction, ,ZOOPHILOLOGICA. Polish Journal of Animal Studies" 2016, nr 2, https://bit.ly/3BieT7J (dostęp: 26.06.2020).

Otto E., Science Fiction and the Ecological Conscience (niepublikowana rozprawa doktorska), University of Florida 2006, https://bit.ly/3ritprz (dostęp: 23.05.2021).

Urbańczyk A., Okrutne, zimne rzeczy. Etyczne kryteria człowieczeństwa w twórczości Philipa K. Dicka na przykładzie „Czy androidy marza o elektrycznych owcach?”, [w:] Oblicza Przedmiotów, red. M. Błaszkowska, K. Bolęba-Bocheńska, Wiele Kropek, Kraków 2019, https:// bit.ly/mprzedm-urbanczyk (dostęp: 26.06.2020).

Werber B., Sa majesté des chats, BernardWerber.com, https://bit.ly/3eAQXT (dostęp: 26.06.2020).

Woleński J., Szowinizm gatunkowy, humanitaryzm i animalocentryzm, „Przegląd Filozoficzny Nowa Seria" 2015, nr 2 (94), https://bit.ly/3ip1fan (dostęp: 26.06.2020).

Zieliński W., Pieśń o Minerwie, czyli kilka słów o relacji kultury i nauki, „Pisma Humanistyczne” 2015, nr 13, https://bit.ly/2UUIHXs (dostęp: 26.06.2020).

\title{
Tomorrow the Cats: (Eco) Science Fiction Problems in Bernard Werber's Novel
}

\author{
Summary
}

Why tomorrow should not belong to humans, but to another species? Science fiction seems to answer this question with alarmingly accurate arguments. SF texts often seem like prophecies that predict the future. We most willingly accept visions in which man is the author of innovative technologies as well as cultural and economic progress. What if this development is not ascribed to the human race, but for example: to monkeys or cats? The classic repertoire of science fiction heroes, apart from humans, includes robots, cyborgs, androids or newcomers from another planet (aliens). Their humanoid character - anthropomorphic features of appearance, behavior, development of the species in the form of created (or mid-creation) civilization and culture — is designed to break the anthropocentric view of man. The function of the Other in science fiction can, however, be taken over by a creature much closer and longer known to man than a newcomer from a foreign planet or a creature of highly developed technology — an animal. The essay is an attempt to analyze Bernard Werber's novel Tomorrow the cats from the perspective of general science fiction and ecofiction issues. At the same time, the issue of species chauvinism and the ways in which it manifests itself in literature are discussed. 
Literatura i Kultura Popularna XXVII, Wrocław 2021

(C) for this edition by CNS 